International Journal of Science and Education, 4(1), 1-15

Uluslararası Bilim ve Eğitim Dergisi, 4(1), 1-15

DOI: 10.47477/ubed.769597

Makale Türü: Araştırma Makalesi

Başvuru Tarihi: 14.07.2020

Yayına Kabul Tarihi: 02.09.2020

\title{
Zenginleştirilmiş Eğitim Programının Geometri Ders ve Görsel Algı Başarısı ile Matematik Tutumuna Etkisi
}

\author{
Enes ULUÇ${ }^{1}$, Kerim GÜNDOĞDU*2
}

Öz

Karma yöntem kullanılarak gerçekleştirilen bu çalışmanın temel amacı Zenginleştirilmiş Eğitim Programının (ZEP) ilkokul 4. sınıf öğrencilerinin geometri ders ve görsel algı başarıları ile matematiğe ilişkin tutumlarına etkisini incelemektir. Aydın ili Efeler ilçesindeki özel bir okulda 4. sınıfta öğrenim gören toplam 37 öğrenci araştırmanın çalışma grubunu oluşturmuştur. Bu öğrenciler 10 hafta boyunca ZEP uygulamaları içeren derslere katılmışlardır. Araştırma verileri; Geometri Başarı Testi (GBT), Matematikle İlgili Düşünceler Anketi, Görsel Alg1 Testi (GAT), öğrenci günlükleri ve araştırmacı günlüğü aracılığı ile toplanmıştır. Nicel verilerin analizinde SPSS 25.00 yardımıyla ortalama ve standart sapma gibi tanımlayıcı istatistikler ile ilişkili örneklemler için t-testi ve Wilcoxon işaretli sıralar testi kullanılmıştır. Nitel analizlerde ise betimsel analiz tekniğine başvurulmuştur. Yapılan t-testleri sonucunda, ilkokul 4. sınıfta uygulanan ZEP'in, öğrencilerin geometri ders başarılarına ve görsel algı becerilerine anlamlı bir katkı sağladığı sonucuna ulaşılmıştır. Ancak programın matematiğe ilişkin olumlu veya olumsuz düşünceler üzerinde anlamlı bir etkisi bulunmamaktadır. ZEP derslerine ilişkin yapılan öğrenci görüşmelerinde derste yer verilen uygulamaların duyuşsal ve bilişsel anlamda oldukça iyi etki bıraktığ görülmüştür.

Anahtar Kelimeler: zenginleştirmiş eğitim programı, geometri başarısı, görsel algı, matematiğe yönelik tutum.

\section{The Effect of Enriched Curriculum on Geometry and Visual Perception Achievements, and Attitudes towards Mathematics}

\begin{abstract}
The purpose of this study, carried out using the mixed method, is to investigate the effect of Enriched Curriculum (EC) on 4th graders ' geometry and visual perception achievements, and attitudes towards mathematics. A total of 37 primary school fourth graders in a private school in the city center of Aydin formed the sample of this study. These students participated in geometry lessons that included EC activities for 10 weeks. Research data were collected by "Geometry Achievement Test (GBT)”, “Thoughts about Mathematic Questionnaire (Attitude Scale)”, "Visual Perception Test (GAT)", student diaries and researcher diary. In the analysis of the quantitative data, $t$ test and Wilcoxon signed rank test were used for the samples related to descriptive statistics such as mean and standard deviation by using SPSS 25.00. As a result of the t-tests, the enriched curriculum implemented for the 4 th graders provided a significant contribution to the students' geometry and visual perception achievements. However, the program has no significant effect on positive or negative thoughts about mathematics. In the student interviews regarding the EC courses, it was observed that the applications included in the course had a very good effect in terms of affective and cognitive.
\end{abstract}

Key Words: enriched curriculum, geometry achievement, visual perception, attitude towards mathematics

\footnotetext{
${ }^{1}$ Classroom Teacher, Aydın Özel Bahçeşehir İlkokulu, aydin@bahcesehir.k12.tr

*2 Corresponding Author: Prof. Dr., Aydın Adnan Menderes Üniversitesi, kerim.gundogdu@adu.edu.tr
} 


\section{Giriş}

Bir ülkenin gelişmişlik düzeyine etki eden önemli unsurlardan birisi de vasıflı iş gücüdür. Ülkeler vatandaşlarının eğitim düzeylerini ne kadar yükseltirlerse ve mevcut eğitim programlarının niteliğini ne derece artırırlarsa aynı oranda bir kalkınma elde edebilirler. Yapılan uluslararası çalı̧̧malar incelendiğinde bu durumu destekler nitelikte olan sonuçlar PISA, TIMMS ve PIRLS gibi projelerde de göze çarpmaktadır. OECD tarafından üç yıllık periyotlar ile uygulanan PISA araştırmasının sonuçlarına göre Türkiye 72 ülke içerisinde 50. sırada kendisine yer bulabilmiştir. Anadilde okuma becerileri, fen okuryazarlığı ve matematik okuryazarlı̆̆ı olmak üzere üç kategoride ölçme değerlendirme yapan bu uygulama sonuçlarına göre PISA 2015'e katılan tüm ülkelerin matematik okuryazarlığında aldıkları puanların ortalaması 461, Türkiye'nin ise 420'dir (MEB, 2015). Türkiye'nin PISA sonuçlarındaki bu tablosu araştırmacıları yeni arayışlara itmektedir.

Eğitim sistemi öğrencilere mevcut potansiyellerini geliştirme, yaratıcı düşünme, bilimsel düşünme, akıl yürütme, problem çözme gibi becerileri kazandıracak özellikleri taşımalı, günlük yaşam becerileri olan görmeye, görsel algıya ve görsel motor becerilerine katkıda bulunacak şekilde zenginleştirilmelidir. 'Zenginleştirilmiş Eğitim Uygulamaları' denildiğinde uygulanan eğitim programlarının çeşitlendirilmesi anlaşılmaktadır. Bu çeşitlendirme bireyin ihtiyacına uygun materyallerle, projelerle, deneylerle, keşfetmeye yönelik etkinliklerle, bilişim teknolojileriyle, çeşitli yarışmalarla, zekâ oyunlarıyla, tasarımlarla gerçekleştirilebilir. Öğrencileri dijital çağa uyumlu kılabilmek için eğitim ve öğretim süreci eğlenceli ve ilgi çekici eğitim ortamları oluşturularak zenginleştirilmelidir. Mevcut programa ek olarak serbest etkinlikler dersleri kapsamında öğrencilerin çeşitli zekâ alanlarına hitap eden, o zekâ alanlarında öğrencinin kendi potansiyelinin üst limitlerine ulaşmasını sağlayacak etkinlikler geliştirilmeli ve bu etkinlikler için gerekli olan çeşitli materyaller ile eğitim programı zenginleştirilmelidir. Zenginleştirilmiş Eğitim Programı (ZEP) kavramı bu şekilde anlaşılmakta ve bilhassa özel eğitim ve öğretim kurumları tarafından bu anlamda kullanılmaktadır (Cutts, 2001; Enç, 2004; Özdemir, 2017; Roberts, 2005).

Türkiye'de eğitim programlarının zenginleştirilmesi üzerine yoğunlaşmış birçok çalışma bulunsa da ZEP uygulamalarının geçmişi ülkemiz adına çok eskilere dayanmamaktadır. Özellikle son on, on beş yıllık süreçte özel okul sayısının artması ile birlikte zenginleştirme faaliyetlerinin uygulamaya başlanması paralel bir gelişim göstermiştir. Zenginleştirme uygulamaları arasında çoğunlukla öne çıkan alt başlıkların "Görsel Algı", "Düşünme Becerileri", "Akıl Oyunları" ve Üretkenlik" gibi kategoriler olduğu görülmektedir. Her okulda farklı isimlerle anılmakla beraber yaygın kullanılan ismiyle ZEP, veliler tarafından da ciddi ilgi görmektedir; fakat bu uygulamalara ve zenginleştirme çalışmalarına yönelik ülkemizde yapılmış değerlendirme çalışmalarının yeterli olmadığı alanyazın taraması sonucunda görülmüştür. Özellikle özel okulların uyguladığı bu program ve kullandığı ilgi çekici materyaller ile hedeflenen kazanımlara ulaşma durumlarını sınama ihtiyacı bu çalışmayı gerekli kılmıştır. Bu nedenle alanyazına bu anlamda bir katkıda bulunmak hedeflenmiştir.

Ülkemizde yapılan araştırmalar incelendiğinde zenginleştirme, geometri başarısı, görsel alg1 becerileri ve matematiğe yönelik tutuma ilişkin birçok çalışma göze çarpmaktadır. Bu çalışmalardan Şahin (2016), Özdemir (2017) ve Marangoz'un (2018) elde ettikleri bulgular, zenginleştirme etkinliklerinin yordanan bağımlı değişkenleri olumlu yönde etkilemeleri bakımından benzerlik göstermektedir. Duatepe (2004), Sarı (2010), Arıcı (2012), Ünlü (2014) ve Demirkıran'ın (2018) ise drama, origami, somut materyaller ile zenginleştirdikleri programın geometri başarısını yordadığı araştırma sonuçları, zenginleştirme çalışmalarının ilgili değişkenleri olumlu yönde etkilemesi ya da uzamsal becerilerle geometri başarısı arasında pozitif yönlü anlamlı ilişkilere işaret etmesi bakımından benzerlik göstermektedir. Zenginleştirme ve görsel algı becerisine yönelik yaptıkları çalışmalarda Bayrak (2008), Demirci (2010), Senger (2010), Özat (2010) ve Altun'un (2017) ulaştıkları sonuçlar da zenginleştirme uygulamalarının görsel algı becerilerine ve öğrenci tutumlarına olumlu etkilerinin bulunduğu 
çıkarımlarına ulaşmaları bakımından benzerlik göstermektedir. Zenginleştirme uygulamalarının öğrencilerin matematiğe ilişkin tutumlarına etkilerinin araştırıldığı bazı çalışmalarda ise Pilli (2008), Özdemirli (2011), Debreli (2011), Curaoğlu (2012), Gençoğlu (2013), Yılmazer (2013), Dönmez (2018) ve Şahin'in (2018) bilgisayar destekli öğretim, işbirlikli öğrenme, yaratıcı drama temelli öğretim, kukla modeli ile öğretim, kavram karikatürü destekli öğretim gibi farklı kategorilerde uyguladıkları program zenginleştirme çalışmalarının, bağımlı değişkenler üzerindeki pozitif yönlü etkilerinden bahsedilmektedir.

Bu çalışmada, araştırmacılar geliştirilen ZEP'in ilkokul 4. sınıf öğrencilerinin geometri ders başarılarına, matematiğe ilişkin tutumlarına ve görsel algı becerilerine ne düzeyde katkı sağladığı belirlenmeye çalışılmıştır. Bu temel amaç doğrultusunda aşağıdaki alt problemlere cevap aranmıştır:

1. ZEP öğrencilerinin geometri ön-test başarı puanları kontrol altına alındığında, düzeltilmiş geometri son-test başarı puan ortalamaları arasında anlamlı bir fark var mıdır?

2. ZEP öğrencilerinin ön-test Görsel Algı puanları kontrol altına alındığında, düzeltilmiş son-test Görsel Algı puan ortalamaları arasında anlamlı bir fark var mıdır?

3. ZEP öğrencilerinin ön-test matematik dersine yönelik tutumları kontrol altına alındığında düzeltilmiş son-test matematik dersi tutumları arasında anlamlı bir fark var mıdır?

4. ZEP uygulamalarına ilişkin öğrencilerin düşünceleri ve araştırmacının gözlemleri nelerdir?

\section{Yöntem}

Bu araştırma yakınsayan paralel desene dayalı, nicel ve nitel araştırma tekniklerinin avantajları birleştirilerek kuvvetlendirilmiş (Baki ve Gökçek, 2012) bir karma yöntem araştırmasıdır. Creswell'in (2003) tanımladığı ve Delice'nin $(2007,2015)$ belirttiği üzere yakınsayan paralel desende araştırmacı nitel ve nicel verileri eş zamanlı toplar ve analiz eder. Ortaya çıkan bulgular birbirini tamamlayıcı ve açıklayıcı rol oynar. Araştırmanın nicel kısmı tek bir grupla çalışma olanağı olduğundan zayıf deneysel desene, nitel kısmı ise bu grubun almış olduğu dersten dolayı, var olan özellikleri durum çalışmasına göre kurgulanmıştır. Durum çalışması "ne", "nasıl" ve "niçin" sorularını merkeze alarak bir veya birden fazla olayı, olguyu ya da durumu kendi doğal ve gerçek ortamında inceleyen, incelenen olay, olgu ya da duruma yönelik birden fazla veri toplama aracı kullanan ve elde edilen verilerin tek başına ya da karşılaştırmalı yorumlanarak olay, olgu ya da durumun derinlemesine incelenmesine olanak sağlayan görgül bir araştırma yöntemidir (Yıldırım ve Şimşek, 2013). Yapılan çalışmada ZEP öncesinde ve sonrasında öğrencilere geometri başarı testi, görsel algı testi ve matematiğe ilişkin tutum ölçeği uygulanmıştır.

\section{Deneysel İşlem}

On hafta süren ZEP uygulamaları boyunca her ders sonrası öğrenci ve araştırmacı günlükleri tutularak yakınsayan desenin gereklerine uyulmuştur. Bu veriler ayrı ayrı analiz edilmiş ve araştırma sonucunu daha iyi yorumlayabilmek için bulgular birlikte yorumlanmıştır. Uygulamanın özel bir okulda yürütülmesi ve ZEP derslerine tüm sınıfların katılıyor olmasından dolayı kontrol grubu oluşturmak mümkün olmamıştır. Bu kapsamda tek grup ön test - son test deneme modeline göre araştırma kurgulanmıştır. Belirlenen iki sınıfa 10 haftalık ZEP uygulaması öncesi ön test, araştırma sonrasında da son test uygulanmış ve bağımsız değişkenin (zenginleştirilmiş eğitim uygulamaları), bağımlı değişkenler (geometri ders başarısı, matematiğe ilişkin tutum ve görsel algı) üzerinde etkisinin olup olmadığı sınanmıştır. Belirlenen kazanımlara ait belirtke tablosu oluşturulmuş ve bu kazanımları temele alarak her ders için ayrı ayrı ders planları hazırlanmıştır. Hazırlanan planlar doğrultusunda ders materyalleri belirlenmiş ve her materyal iki hafta süreyle sınıfta kullanılmıştır. 


\section{Çalışma Grubu}

Çalışma grubunu Aydın ili Efeler ilçesinde bulunan özel bir okulda ilkokul 4. sınıfta 18'i kız ve 19'u erkek toplam 37 öğrenci oluşturmuştur. Öğrenciler her hafta 40 dakikalık bir oturumu içerecek şekilde 10 hafta boyunca zenginleştirme derslerine katılmışlardır. ZEP derslerine tüm sınıfların katılıyor olmasından dolayı kontrol grubu oluşturulamamış ve tek grup ön test-son test deneme modeline göre araştırma yürütülmüştür.

\section{Veri Toplama Araçları}

Araştırma verileri araştırmacı tarafından pilot çalışmaları yapılarak Bloom'un yenilenmiş taksonomisine göre geliştirilen, dörder seçenekli 20 sorudan oluşan bir 'Geometri Başarı Testi' (GBT, ort. zorluk=0.68); yine araştırmacı tarafından pilot denemeleri yapılarak geliştirilen, çoktan seçmeli 13 soruyu içeren bir 'Görsel Algı Testi' (GAT, ort. zorluk=0.74) ve İflazoğlu (1999) tarafından geliştirilen 26 maddelik "Matematik Tutum Ölçeği" aracılığıyla toplanmıştır. GBT'nin değerlendirmesi doğru cevaplanan her soruya 5 puan verilerek toplam 100 puan üzerinden yapılmıştır. Dolayısiyla testten alınabilecek en düşük puan 0, en yüksek puan ise 100 'dür. GAT'nin değerlendirmesi ise doğru cevaplanan her soruya 7,69 puan verilerek toplam 100 puan üzerinden yapılmıştır. Dolayısıyla testten alınabilecek en düşük puan 0, en yüksek puan 100'dür. Matematik Tutum Ölçeğinde ise genel bir puanlama yapılmayıp puanlama "Matematikle İlgili Olumlu Düşünceler" ve "Matematikle İlgili Olumsuz Düşünceler" alt boyutlarına göre ayrı ayrı yapılmıştır. GBT'nin güvenirliği 0.85; GAT'nin güvenirliği 0.71 ve MDA güvenirliği ise 0.97 bulunmuştur. Yıldırım ve Şimşek'in (2013) de belirttiği gibi karma yöntem araştırmalarının önemli özelliklerinden bir tanesi de elde edilen nitel ve nicel verilerin birbirlerini açıklamasını ya da desteklemesini sağlamak ve bu yolla çalışmanın güvenirliğini ve elde edilen sonuçların doğruluğunu artırmaktır. Bu bağlamda, nitel verilerin toplanması sürecinde öğrenci ve araştırmacı günlüklerinden faydalanılmıştır. Günlükler öğrencilerin içeriğe ilişkin farkındalıklarını ölçmek, etkinlikler esnasında anladıklarını ya da anlamadıklarını, yapabildiklerini ya da yapamadıklarını tespit edebilmek, derste nasıl vakit geçirdiklerini bizzat onların ağzından öğrenebilmek ve derse ilişkin önerilerine kulak verebilmek için dört maddeden oluşacak şekilde yapılandırılmıştır. Öğrenci günlükleri ile eş zamanlı olarak yine karşılaştırmayı kolaylaştırmak bakımından aynı dört başlıkta araştırmacı günlügü tutulmuştur.

\section{Verilerin Toplanması}

Belirlenen iki sınıfa 10 haftalık ZEP uygulaması öncesi ön test, araştırma sonrasında da son test uygulanmış ve bağımsız değişkenin (zenginleştirilmiş eğitim uygulamaları), bağımlı değişkenler (geometri ders başarısı, matematiğe ilişkin tutum ve görsel alg1) üzerinde etkisi sınanmıştır. Yapılan çalışmada ZEP öncesinde ve sonrasında öğrencilere geometri başarı testi, görsel algı testi ve matematiğe ilişkin tutum ölçeği uygulanmıştır. Eş zamanlı olarak on hafta süren Zenginleştirilmiş Eğitim Programı boyunca her ders sonrası öğrenci ve araştırmacı günlükleri tutularak yakınsayan desenin gereklerine uyulmuştur. Bu veriler ayrı ayrı analiz edilmiş ve araştırma sonucunu daha iyi yorumlayabilmek için bulgular birlikte yorumlanmıştır.

Araştırmacı, öğrenci günlükleri ile öğrencilerin sürece aktif katılımlarını ve süreçle ilgili gerçek düşüncelerini elde edebilmeyi amaçlamıştır. Her hafta uygulama dersinin son beş dakikasında öğrenciler kendilerine ait günlükleri araştırmacının rehberliğinde doldurmuşlardır. Bununla birlikte araştırmacı da aynı zamanda gözlemci olduğu için her ders sonrasında kendi gözlemlerini araştırmacı günlügüne aktarmıştır. On haftalık süreç sonunda öğrenci günlüklerine ve araştırmacı günlüğüne ilişkin tema ve kodlar belirlenerek bu günlükler betimsel analiz incelenmiştir. 


\section{Verilerin Analizi}

İstatistik paket programı yardımıyla ortalama ve standart sapma gibi tanımlayıcı istatistikler ile ilişkili örneklemler (paired samples) t-testi ve Wilcoxon İşaretli Sıralar Testi kullanılmıştır. Testlerde Ancova için gerekli şart olan normallik ve en az iki grup şartı sağlanmadığı için kovaryans analizi yapılmamıştır. T-testi sonuçlarında veriler $\mathrm{p}<0,05$ anlamlılık düzeyinde ve \%95 güven aralığında hesaplanmıştır. Betimsel analiz, derinlemesine analiz gerektirmeyen verilerin işlenmesinde kullanılırken, temel amaç görüşme ve gözlem sonucu elde edilen verilerin düzenlenmiş ve yorumlanmış bir şekilde okuyucuya sunulmasıdır. Veriler, bu çalışma kapsamında yer verildiği üzere, daha önceden belirlenmiş temalara göre sınıflandırılır, özetlenir ve yorumlanır. Bulgular arasında neden-sonuç ilişkisi kurulur ve karşılaştırmalar yapılır (Yıldırım ve Şimşek, 2013). Öğrenci ve araştırmacı günlükleri bu bağlamda incelenmiş ve içerik analizi yapılırken öğrenci görüşleri her öğrenciye bir numara belirlenerek "Ö" harfiyle temsillenmiştir.

\section{ZEP Uygulamalarının Geometri Ders Başarısı, Tutum ve Görsel Algıya Etkisi}

Tablo 1. ZEP Uygulamalarının Geometri Ders Başarısına Etkisine İlişkin Wilcoxon İşaretli Sıralar Testi Bulguları

\begin{tabular}{llllcccc}
\hline $\begin{array}{l}\text { Geometri } \\
\text { BasarıTesti }\end{array}$ & $\mathrm{N}$ & Siralar & $\mathrm{N}$ & Sira Ort. & Sira Top. & $\mathrm{Z}$ & $\mathrm{p}$ \\
Ön Test & 37 & Negatif & $8^{\mathrm{a}}$ & 11,75 & 96,0 & & \\
Son Test & 37 & Pozitif & $2^{\mathrm{b}}$ & 16,86 & 369,0 & $-2,884$ & $\mathbf{0 , 0 0 4}$ \\
\hline
\end{tabular}

ZEP uygulamalarının geometri ders başarısına etkisini tespit etmek amacıyla yapılan Wilcoxon İşaretli Sıralar Testi sonucunda ulaşılan bulgular Tablo 1'de verilmiştir. Buna göre, geometri başarı testi ön test ve son test puan ortalamaları anlamlı farklılık göstermiştir $(\mathrm{z}=-2,884 ; \mathrm{p}=0,004<0,05)$. Fark, son test lehinedir. Yani, ZEP uygulamalarının öğrencilerin geometri ders başarılarını anlamlı ölçüde artırdığı söylenebilir

Tablo 2. ZEP Uygulamalarının Görsel Ayırt Etme ve Şekil-Zemin İlişkisi Üzerindeki Etkisine İlişkin Bulgular

\begin{tabular}{|c|c|c|c|c|c|c|c|c|}
\hline \multicolumn{2}{|c|}{ Görsel Alg1 Testi } & $\mathrm{N}$ & Siralar & $\mathrm{N}$ & Sira Ort. & Sira Top. & Z & $\mathrm{p}$ \\
\hline \multirow{3}{*}{$\begin{array}{l}\text { Görsel } \\
\text { Ayırt Etme }\end{array}$} & \multirow{2}{*}{ Ön Test } & \multirow{2}{*}{37} & Negatif & $6^{a}$ & 6,25 & 37,50 & \multirow{3}{*}{$-1,151$} & \multirow{3}{*}{0,250} \\
\hline & & & Pozitif & $9^{b}$ & 9,17 & 82,50 & & \\
\hline & Son Test & 37 & Eşit & $22^{c}$ & & & & \\
\hline \multirow{3}{*}{$\begin{array}{l}\text { Şekil } \\
\text { Zemin } \\
\text { İlişkisi }\end{array}$} & \multirow{2}{*}{ Ön Test } & \multirow{2}{*}{37} & Negatif & $8^{a}$ & 10,21 & 71,50 & & \\
\hline & & & Pozitif & $14^{\mathrm{b}}$ & 11,39 & 159,50 & $-1,436$ & 0,151 \\
\hline & Son Test & 37 & Eşit & $15^{c}$ & & & & \\
\hline
\end{tabular}

a Ön test $<$ Son test, $b$ Ön test $>$ Son test, $\mathrm{c}$ Ön test $=$ Son test.

ZEP uygulamalarının görsel algı başarısına etkisini tespit etmek amacıyla nonparametrik özellik gösteren görsel ayırt etme ve şekil-zemin ilişkisi puanları Wilcoxon İşaretli Sıralar Testi ile karşılaştırılmıştır. Ulaşılan bulgular Tablo 2'de verilmiştir. Buna göre, görsel algı testinin ilk alt boyutu olan görsel ayırt etme ön test ve son test puan ortalamaları anlamlı farklılık göstermemiştir $(z=-1,1151$; $\mathrm{p}=0,25>0,05)$.Yani, ZEP uygulamalarının öğrencilerin görsel ayırt etme becerilerini anlamlı ölçüde etkilemediği söylenebilir. Şekil-zemin ilişkisi alt boyutunda da ön test ve son test puan ortalamaları 
anlamlı farklılık göstermemiştir $(\mathrm{z}=-1,436 ; \mathrm{p}=0,151>0,05)$. Yani, ZEP uygulamalarının öğrencilerin şekil zemin ilişkisi becerilerini anlamlı ölçüde etkilemediği söylenebilir.

Tablo 3. ZEP Uygulamalarının Şekil - Zemin Ayrımı ve Görsel Algı Toplam Puanı Üzerindeki Etkisine İlişkin Bulgular

\begin{tabular}{|c|c|c|c|c|c|c|c|c|}
\hline Görsel Alg1 Testi & & $\mathbf{N}$ & Ort. & Ss. & $\begin{array}{l}\text { Ort. } \\
\text { Aras1 } \\
\text { Fark } \\
\end{array}$ & $\mathbf{t}$ & Sd & $\mathrm{p}^{*}$ \\
\hline \multirow{2}{*}{ Şekil - Zemin Ayrımı } & Ön Test & 37 & 1,56 & 1,08 & \multirow{2}{*}{0,49} & \multirow{2}{*}{$-2,372$} & \multirow{2}{*}{36} & \multirow{2}{*}{0,023} \\
\hline & Son Test & 37 & 2,05 & 1,13 & & & & \\
\hline \multirow{2}{*}{ Görsel Alg1 } & Ön Test & 37 & 9,89 & 2,09 & \multirow{2}{*}{8,52} & \multirow{2}{*}{$-3,788$} & \multirow{2}{*}{36} & \multirow{2}{*}{0,001} \\
\hline & Son Test & 37 & 10,81 & 1,96 & & & & \\
\hline
\end{tabular}

* $\mathrm{p}<0,05$ anlamlılık düzeyinde ve $\% 95$ güven aralığında.

Parametrik özellik gösteren şekil - zemin ayrımı ve görsel algı toplam puanı sonuçları ise ilişkili örneklemler t-testi ile karşılaştırılmıştır. Ulaşılan bulgular Tablo 3'de verilmiştir. Buna göre, şekil zemin ayrımı ön test ve son test puan ortalamaları son test lehine anlamlı farklılık göstermiştir $(\mathrm{t}=-2,372$; $\mathrm{p}=0,023<0,05)$. Buna göre ZEP uygulamalarının öğrencilerin şekil - zemin ayrımı becerilerine anlamlı ölçüde katkı sağladığı söylenebilir. Genel toplamda ise görsel alg1 ön test ve son test puan ortalamaları anlamlı farklılık göstermiştir $(t=-3,788 ; \mathrm{p}=0,001<0,05)$. Fark, son test lehinedir. Yani, ZEP uygulamalarının öğrencilerin görsel algı becerilerini anlamlı ölçüde artırdığı söylenebilir.

Tablo 4. ZEP Uygulamalarının Matematiğe İlişkin Tutumlara Etkisine İlişkin t-testi Bulguları

\begin{tabular}{|c|c|c|c|c|c|c|c|c|c|}
\hline Faktör & & $\mathrm{N}$ & Ort. & Ss. & $\begin{array}{l}\text { Ort. } \\
\text { Fark }\end{array}$ & Aras 1 & $t$ & Sd & $\mathrm{p}^{*}$ \\
\hline \multirow[t]{2}{*}{ Olumlu Düşünceler } & Ön Test & 37 & 3.29 & 1.24 & \multirow{2}{*}{\multicolumn{2}{|c|}{-0.08}} & \multirow[t]{2}{*}{0.922} & \multirow[t]{2}{*}{36} & \multirow[t]{2}{*}{.363} \\
\hline & Son Test & 37 & 3.21 & 1.08 & & & & & \\
\hline \multirow{2}{*}{$\begin{array}{l}\text { Olumsuz } \\
\text { Düşünceler }\end{array}$} & Ön Test & 37 & 2.59 & 0.98 & \multirow[t]{2}{*}{-0.08} & & \multirow[t]{2}{*}{1.031} & \multirow[t]{2}{*}{36} & \multirow[t]{2}{*}{.309} \\
\hline & Son Test & 37 & 2.51 & 0.99 & & & & & \\
\hline
\end{tabular}

* p<.05 anlamlılık düzeyinde ve \%95 güven aralığında.

ZEP uygulamalarının matematiğe ilişkin tutumlara etkisini tespit etmek amacıyla yapılan ilişkili örneklemler t-testi sonucunda ulaşılan bulgular Tablo 4'de verilmiştir. Buna göre, öğrencilerin matematiğe ilişkin olumlu düşünceleri 0,08 puan azalmasına rağmen bu fark istatistiksel olarak anlamlı değildir ( $\mathrm{t}=-0.922 ; \mathrm{p}=.363>0,05)$. Yani, ZEP uygulamalarının öğrencilerin matematiğe ilişkin olumlu düşüncelerine anlamlı bir katkıda bulunmadığı söylenebilir. Öğrencilerin matematiğe ilişkin olumsuz düşünceleri 0,08 puan azalmakla birlikte, bu fark da istatistiksel olarak anlamlı değildir ( $\mathrm{t}=1.031$; $\mathrm{p}=.309>0,05)$. Yani, ZEP uygulamalarının öğrencilerin matematiğe ilişkin olumsuz düşüncelerine anlamlı bir katkıda bulunmadığı söylenebilir. Bunun yanında toplam 26 maddeye ait ön test ve son test ortalamaları t-testine tabi tutulduğunda maddelerin hiçbirinde istatistiksel olarak anlamlı bir fark olmadığı tespit edilmiştir. Yani ZEP uygulamaları hiçbir madde ortalamasını anlamlı olarak etkilememiştir ( $\mathrm{p}>.05)$.

\section{ZEP Uygulamalarına İlişkin Öğrenci ve Araştırmacı Görüşleri}

Araştırmacı, öğrenci günlükleri ile öğrencilerin sürece aktif katılımlarını ve süreçle ilgili gerçek düşüncelerini elde edebilmeyi amaçlamıştır. Her hafta uygulama dersinin son beş dakikasında 
öğrenciler kendilerine ait günlükleri araştırmacının yönlendirmeleriyle doldurmuşlardır. Bununla birlikte araştırmacı da aynı zamanda gözlemci olduğu için her ders sonrasında kendi gözlemlerini araştırmacı günlügüne not almıştır. On haftalık süreç sonunda öğrenci günlüklerine ve araştırmacı günlügüne ilişkin kodlar aracılığıyla temalar belirlenmiştir. Bu bağlamda hem öğrenci günlüklerinin hem de araştırmacı günlügünün analizi için gerekli temalar "İçeriğe ilişkin farkındalık, Uygulamalara ilişkin anlaşılan/yapılabilenler, Uygulamaya ilişkin anlaşılmayan/yapılamayanlar, Uygulama dersine karşı tutum, Uygulamalara ilişkin yeni fikir ve öneriler" olmak üzere belirlenmiştir. Belirlenen tema ve kodlar doğrultusunda bu günlükler betimsel analizi ile incelenmiştir.

\section{Öğrenci Günlüklerine İlişkin Bulgular}

\section{İçeriğe ilişkin farkındalık}

Öğrenciler on haftalık süreçte yapılan uygulamalarda daha çok grup çalışmalarının gerçekleştirildiğini belirtmişlerdir. Bu grupların yapılan etkinliğin veya kullanılan materyalin durumuna göre iki ya da dört kişiden oluştuğu görülmektedir. Birkaç örnekle yakından bakmak gerekirse bazı öğrenci cevapları şu şekildedir:

\section{Bugünkü Z.E.P. dersinde neler yaptım?}

Ö.30. (1. hafta) - Look Look oynadık, kendimi iyi hissettim. Grup başkanı seçtik.

Ö.3. (2. hafta) Bu hafta geçen haftadan daha hızlıydı. Çünkü kartları daha hızh bulduk. Bu sefer ben sinuf birincisi oldum.

Öğrencilerin cevaplarına bakıldığında ZEP dersine yönelik olarak bazı öğrencilerin not ettiği tanımlamalar, duygular ve düşünceler şu şekildedir:

Ö.15. (3. hafta) Abalone oynadık ve çok eğlenceliydi. Ben iki kere elendim ama her oyunda kazanmak da var kaybetmek de. Ve arkadaşımı tebrik ettim.

Ö.30. (5. hafta) Mimarlık oyunu oynadık. Oynamadan önce hoca oyunu bize anlattı. Çok zevkli geçti. Bu oyun arkadaşımla yarış yapma oyunu değildi.

Yukarıdaki cevaplara bakıldığında gruplar halinde yapılan etkinliklerin çokluğunun öğrenciler arasında rekabete yol açtı̆̆ı söylenebilir. Öğrencilerin cevaplarında "kazanmak, birinci olmak, kaybetmek, yenilmek, yarışmak vb." ifadelere sıklıkla rastlanılmıştır. Bunun yanı sıra görülen bir başka durum ise öğrencilerin derste gerçekleştirilen faaliyetleri ve dersin kendisini sıradan olarak tanımlamak yerine dersi ve etkinlikleri eğlenceli oyunlar olarak tarif etmeleridir. Dikkat çeken bir başka nokta da öğrencilerin derste yapılan etkinlikleri başka disiplinlerle ilişkilendirmeleri ve bu etkinliklerin kendilerine yapacağını düşündükleri katkılardan söz etmeleridir.

\section{Uygulamalara ilişkin anlaşılanlar/yapılabilenler}

Bu bölümde öğrencilerin ZEP derslerinde anlayabildikleri ve yapabildiklerini değerlendirmeleri amaçlanmıştır. Öğrencilerin cevapları detaylı olarak incelendiğinde dile getirilen bazı öğrenci görüşleri aşağıda verilmiştir:

Daha iyi anladıklarım/yapabildiklerim:

Ö.18. (5. hafta) Şekilleri yapmada daha iyiyim.

Ö.6. (1. hafta) Toplama ve çıkarmayı normal yaptığımdan çok daha hızlı ve eğlenceli oldu.

Ö.32. (10. hafta) Aynı renkleri yerleştirmek.

Yukarıdaki cevaplara bakıldığında öğrencilerin etkinlik amaçlarını genel olarak anladıkları görülmüştür. Şekil bulma ve şekilleri eşleştirmede de öğrenciler kendilerini başarılı görmüşlerdir. Yine 
bunun yanında matematiksel işlem becerileri (toplama-çıkarma) gerektiren etkinliklerde de iyi olduklarını belirtmişlerdir.

\section{Uygulamaya ilişkin anlaşılmayan/yapılamayanlar}

$\mathrm{Bu}$ bölümde öğrencilerin uygulamalarda yaşadıkları zorluklara ve etkinliklere ilişkin anlayamadıkları veya yapamadıkları noktalara mercek tutulmaya çalışılmıştır. Bazı öğrenci görüşleri şöyledir:

Anlamadiklarım/yapamadiklarım:

Ö.20. (1. hafta) Stres oluyorum.

Ö.18. (2. hafta) İkisinin arasındaki aynı şekli bulmayı daha yavaş buluyorum.

Ö.19. (3. hafta) Bazı arkadaşlarımı yenemiyorum.

Ö.6. (5. hafta) Bazıları hemen yıkıldı. Bazılarını dengede tuttum, bazılarım dengede tutamadım.

Yukarıdaki cevaplar göz önünde bulundurulduğunda bu görüşlerin genellikle ilgili haftanın etkinliği hakkında olduğu görülmüştür. Öğrenciler on haftalık uygulama sürecinde genel olarak anlamadıkları veya yapamadıkları bir şey olmadığını belirtseler de olumsuz görüş bildiren öğrenciler Look Look etkinliğinde bazı eşleştirmelerde zorlandıklarını ve arkadaşlarıyla yarıştıkları için stres yaşadıklarını, Abalone etkinliğinde strateji geliştirmekte problem yaşadıklarını, Equlibrio etkinliğinde taşları dengede tutmakta zorlandıklarını, Dizios etkinliğinde ise örüntü oluştururken üç veya dört renk içeren kartları doğru yerlere yerleştirmede takıldıklarını belirtmişlerdir.

\section{Uygulama dersine yönelik tutum}

Öğrencilerin ZEP dersinde geçirdikleri vakte ilişkin değerlendirmeleri genel olarak olumlu ifadeler etrafında kümelenmiştir. Bu görüşlerin yanı sıra seyrek de olsa bazı öğrencilerin olumsuz görüşleri de ilgili haftaya özel olarak görülmüştür. Bunlara birkaç örnek vermek gerekirse:

Bu hafta Z.E.P. dersinde diğer derslere göre nasll vakit geçirdim?

Ö.30. (3. hafta) Çok güzel geçti. Matematikten daha güzel... Bu derste Abalone oynadı̆̆ımız için çok güzel geçti.

Ö.27. (6. hafta) Korku, heyecan, sevinç ve üzüntü yaşadık. Çünkü taşları üstüste koymak ve dengede tutmak bunlar zor ayarlanabildiği için bu duyguları çok sık yaşadım.

Ö.36. (2. hafta) Çok çok kötü geçti. Zor şekiller geldi.

Ö.2. (4. hafta) Hep yenildim, mutsuz oldum. Ama yine de güzeldi.

Öğrenci günlükleri bu noktada çok net sonuçlar vermiş ve diğer derslere nispeten öğrencilerin ZEP dersine karşı daha olumlu bir tutum takındıkları, dersi daha eğlenceli buldukları görülmüştür. Olumsuz görüşler ise ZEP dersini diğer derslere göre olumsuz görmemektedir. Bazı öğrenciler ZEP dersini kendi içerisinde değerlendirerek önceki haftalarla karşılaştırmalar yapmıştır.

\section{Uygulamalara ilişkin yeni fikir ve öneriler}

Bu bölümde öğrencilerin derse ilişkin yeni öneriler getirmeleri hedeflenmiş ve tüm sınıfa beyin fırtınası yaptırılmaya çalışılmıştır. Öğrenci değerlendirmelerine bakıldığında, önerilerin ilgili haftanın materyali özelinde veya ZEP dersinin genel uygulanışı üzerinde olmak üzere ikiye ayrıldığı görülmektedir. Öncelikle spesifik önerilere göz atacak olursak bazı öğrenci görüşleri şu şekildedir:

Sen olsan bugünkü derste neyi farkh yapardın?

Ö.10. (1. hafta) Look Look'ta kartın anlamını üstüne yazsalardı iyi olurdu. (Look Look) 
Ö.1. (3. Hafta) Keşke Abalone'da dörtlü ilerleme olsaydı. (Abalone)

Ö.14. (6. hafta) Farklı geometrik şekiller de olsaydr. Mesela koni olabilirdi. (Equlibrio)

Ö.17. (6. hafta) Taşlar yapışkanlı olsaydı düşmezdi. (Equlibrio)

Ö.15. (7. hafta) Keşke renkleri (taşları) yerinden kaldırmak olsaydı. (Square Up)

Öğrencilerin hafta fark etmeksizin üzerinde fikir birliğine vardığı bazı görüşler de bu değerlendirme sorusu altında bir araya getirilmiştir. Öğrencilerin ortak görüşe sahip olduklarının göze çarptığı bazı cevaplar ise şu şekildedir:

Ö.21. (6. hafta) Daha büyük masalar olsaydı. Çok kişi otursaydr. Hoşuma gitmedi.

Ö.18. (2. hafta) Daha sessiz olsaydı. Sonuncular da alkışlanmalı.

Ö.18. (5. Hafta) Daha az kişi, sessizlik ve daha çok vakit (süre) isterdim. Çünkü bu oyuna bayıldım.

ZEP uygulamalarının kurgulanması konusunda öğrencilerden gelebilecek akılcı ve yenilikçi fikirler son derece değerlidir. Uygulayıcının gözünden kaçan aksaklıkları tespit etmek için öğrencilerin görüşleri öğrenilmeye çalışılmıştır.

Öğrenciler bazı bireysel etkinliklerin yarışma şeklinde yapılmasını yeğlediklerini, sınıfta bulunan masaların daha büyük olması, yapılan etkinlikler esnasında daha sessiz olunması ve derse katılan öğrenci sayısının daha az olması gerektiğini belirtmişlerdir. Bu görüşlerin yanı sıra öğrencilerin ZEP dersinde sürenin daha uzun olmasını istedikleri de görülmüştür.

\section{Araştırmacı Günlüğüne İlişkin Bulgular}

\section{İçeriğe ilişkin farkındalık}

Araştırmacı günlüğündeki içerikle ilgili bölümlere ait bazı cevaplar şu şekildedir:

(1. hafta) ZEP uygulamalarının ilk haftası olması sebebiyle öncelikle öğrencilere dersin içeriği ile ilgili kısa bir bilgi verildi ve bu uygulamalar boyunca uyulması gereken sınıf kuralları ile ilgili fikir alışverişine dayalı bir çerçeve çizildi.

(9. hafta) Çocuklar etkinliği ilk kez gördükleri için daha önceden yapıldı̆̆ı gibi bir masa etrafında toplanıp çocuklara materyal tanitıldı ve etkinlik esnasinda uyulması gereken kurallar belirtildi.

(2. hafta) Bunun yerine bir önceki derste öğrencilerin etkinliği tamamlamadaki başarllarına göre etkinlik gruplarında revizyona gittim. Bir önceki araştırmacı günlüğümde öneriler bölümünde belirttiğim üzere öğrencileri bu sefer seviyelerine göre grupladım.

ZEP dersinde materyalleri tanıtmak, hedefleri açıklamak ve kuralları benimsetmek ilk yapılması gereken iştir. Yukarıdaki cevaplara bakıldığında araştırmacının, materyallere ilişkin kurallar konusunda öğrencilerle tek yönlü bir iletişim kursa da sınıf kuralları ile ilgili onların da katılımını sağlayarak, üzerinde herkesin ortak bir görüşte birleştiği bir şablonu ortaya koyduğu söylenebilir. Bunun yanı sıra bazı etkinliklerin bireysel bazı etkinliklerin ise iki, üç veya dört kişilik gruplarla sürdürülmesi gerektiği için gruplar halinde devam ettirilecek etkinliklerde olası çatışmaların önüne geçilmeye çalışıldığı da görülmektedir.

\section{Araştırmacının gözlemlediği olumlu davranışlar}

Etkinlikler boyunca yapılan gözlemlerde öğrencilerin çeşitli olumlu davranışları kaydedilmiştir. Araştırmacının buna ilişkin aldığı notlardan bazıları şu şekildedir:

(1. hafta ) Öğrenciler ilk kez yaptıkları bu etkinlikte sayı ve figür bulma, toplama ve çıkarma işlemlerini yapma konusunda yeterli başarııı gösterdiler. 
(6. hafta) Öğrenciler şekilleri algılama, tahmin etme, yerleştirme konularında daha başarıllydılar. Hangi şeklin silindir, hangisinin üçgen prizma, kare prizma, dikdörtgenler prizması olduğunu daha hızlı kavradılar ve matematik dersinde öğrendikleriyle özdeşleştirdiler.

(9. hafta) Öğrenciler genel olarak örüntü kavramına matematik derslerinden hakim oldukları için etkinliğin mantı̆̆ını çabuk kavradılar ve uygulamaya koyuldular.

(3. hafta) Öğgrencilerin merak ettikleri bir etkinliğe karşı öğrenme heveslerinin arttığı açıktı...

...Yarışma temelli bir oyun olması bakımından yenilen öğrencilerin heveslerinin kırılabileceğini öngörüyordum ama bu hususta yanıldım. Kaybeden öğrenciler aynı motivasyonla etkinliğe baştan başladılar ve arkadaşlarını da tebrik etme olgunluğunu gösterdiler.

Ders ders tutulmuş olan notlarda öğrencilerin sınıf ve etkinlik kurallarına genellikle uyduklarına çokça değinilmiştir:

((8. hafta) Kuralları çiğnemeden ve sinıftaki sessizliği bozmadan etkinliğe odaklandılar.

Öğrencilerin etkinlikleri ve etkinlik kurallarını kavrama, etkinliğe hevesle devam etme, etkinlik ve sınıf kurallarına uyma, grup ya da sınıf arkadaşlarını tebrik etme gibi davranışları gözlemlenmiştir. Öğrencilere ilişkin gözlemlenen bir diğer olumlu nokta da derse ve materyalleri öğrenmeye ilişkin son derece hevesli olmaları, bu yüzden ZEP derslerinin sayısının artırılmasını istemeleridir. Öğrencilerin verdikleri cevaplara bakıldığında arkadaşlarıyla yarışma fikrinin çok eğlenceli geldiği ve bu düşüncelerinin öğrencilerin motivasyonlarını dersin sonuna kadar korumalarını sağladığı söylenebilir. $\mathrm{Bu}$ hevesin meraktan ileri geldiği düşünülmektedir. Bunun yanı sıra derse ilişkin hevesleri onları bencilleştirmemiş, ders sonunda öğrencilerin birbirlerini tebrik ettikleri görülmüştür.

\section{Araştırmacının gözlemlediği olumsuz davranışlar}

ZEP dersleri öğrencilerin genel anlamda iyi vakit geçirdikleri ve etkinlikleri hevesle devam ettirdikleri süreçlerden oluşmaktadır. Buna rağmen öğrencilerin kavramakta zorlandıkları kurallar ve detaylar olmuştur. Araştırmacı günlüğünde de buna ilişkin alınmış notlar şu şekildedir:

(1. hafta) İki renkli kart içindeki ortak figürü bulma konusunda öğrencilerin zorlandiğını gözlemledim. Bu durumun eşleştirme konusundaki geçmiş tecrübelerinin eksikliğinden kaynaklandı̆̆ını düşünmekteyim.

(4. hafta) Strateji geliştirme konusunda öğrencilerden bazılarının ileri gidemediğini fark ettim. Satranç, Abalone gibi strateji gerektiren oyunlarda oyuncular fevri hareket etmez, bir veya birkaç hamle sonrasinı planlarlar. Öğrencilerin bazıları bu beceriyi gösterseler de çoğunluk "Nasıl olsa yenilsem de tekrar oynayacă̆ım." düşüncesiyle bir eylem planı kurgulamadan etkinliği sürdürüyorlardı.

(5. hafta) Öğrenciler bu etkinlikte en çok materyalleri dengede tutma konusunda sıkıntı yaşadılar.

(9. hafta) Bazı öğrenciler bir kartın birden fazla kartla temas etmesi halinde temas ettiği tüm kartlarla uyumlu olması gerektiğini ilk etapta kavramakta zorlandılar.

Yukarıda birkaç örneği verilen öğrenci cevaplarına genel olarak bakıldığında olumsuz görüşlerin birçoğunun bireysel farklılıklardan ve öğrencilerin yeterli hazırbulunuşluğa sahip olmamalarından kaynaklı olabileceği düşünülebilir. Öğrencilerin figür bulma veya figürleri eşleştirmede zorlanma, bazı materyallerde dengeyi kurma ve koruma, oyun kuralları anlatıldığı halde uygulama aşamasında kural ihlali yapma, materyale yönelik strateji geliştirememe gibi problemlerle karşılaştıkları görülmüştür.

\section{Uygulama dersine ilişkin öğrenci tutumlarına yönelik gözlemler}

ZEP dersleri öncesinde ve sırasında öğrencilerin derse ve materyallere karşı son derece istekli oldukları gözlemlenmiştir. Araştırmacı gözlemlerinden bazıları şu şekildedir: 
(3. hafta) Öğrenciler materyalin uygulanışı gereği etkinliğe daha motive göründüler. Bazı öğrenciler dersin bittiği söylenmesine rağmen ek süre talep edip devam etmek istediler. Diğer derslerde teneffüs ziliyle dışar koşan öğrenciler yerine zile rağmen yerinden kalkmayan öğrenciler vardl.

(9. hafta) ZEP dersi her yeni materyalde çocuklara farklı bir heyecan ve merak yüklüyor. Dolayısıla yeni etkinliğe geçtiğimiz bu haftada da öğrencilerin diğer derslere göre daha kaliteli ve eğlenceli vakit geçirdiklerini söyleyebilirim. Bir yandan da bu derslerin mihver derslere yönelik çocukların bakış açılarını değgiş̧tirebileceğginden ve motivasyonların düşürebileceğinden endişe etmeye başladım.

Öğrencilerin ZEP derslerine yönelik motivasyonlarının haftadan haftaya düşmesi olası bir senaryo olarak beklenilmesine karşın, öğrencilerin hem kısa hem uzun vadede motivasyonlarını korudukları, öğrenci günlüklerinde olduğu gibi araştırmacı günlüğünde de dikkat çekmektedir. Dolayısıyla öğrencileri güdüleme noktasında sorun yaşanmadığı tespiti yapılmıştır. Gözlem notlarında da belirtildiği üzere öğrenciler eğlenceli ve iyi vakit geçirdiklerini sıkça dile getirmişlerdir. Bu noktada ZEP derslerinin mihver derslere göre daha renkli geçmesinin, öğrencilerin mihver derslere karşı tutumlarını olumsuz etkileyebileceği tahmin edilebilir. Aynı şekilde matematik dersine karşı tutum anketi de bu endişeyi destekler nitelikte sonuçlar vermiştir.

\section{Uygulamalara ilişkin yeni fikir ve öneriler}

Uygulamaya yönelik araştırmacı görüşleri birkaç başlık etrafında kümelenmiştir. Bu görüşlerden bazıları günlükte haftalık olarak aşağıdaki şekilde yer almıştır:

(1. hafta) Öğrenciler arasında hazır bulunuşluk farkları olduğu için gruplar oluşturulurken bu farklar gözetilerek eşleştirmeler yapılmalıdır. Aksi takdirde grup içerisinde geride kalan öğrenci demoralize olabiliyor.

(4. hafta) Bunun yanı sira kazanan her masanın etkinlik skoru tutulabilir ve ders sonunda başarll öğrencilere verilmek üzere olumlu pekiştireçler planlanabilir. İki öğrencinin birbiriyle yarışması ve rakibinin taşlarını egale etmesi üzerine kurgulanmış bir etkinlik olduğu için her öğrencinin, rakibinin hamlelerinin doğruluğunu kontrol etmesi gerektiğini düşünüyorum. Bu görev öğrencinin aynı zamanda strateji geliştirmesine de katkı sağlayabilir.

(5. hafta) Bireysel bir etkinlik olması hasebiyle öğrenciler her görev kartı bitiminde öğretmeni çă̆ırmak durumundaydılar. Bu noktada sinıfta gürültü oluştuğunu söyleyebilirim. Bu gürültünün yok edilmesi için etkinliğini tamamlayan her öğrencinin el kaldırıp gözlemciyi çă̆ırmasını önerebilirim. Dersin yarısından itibaren ben de bunu uyguladim.

(10. hafta) Dizios, renkler ve şekillerle iki boyutlu örüntüler oluşturma esasına dayanan bir materyaldir. Dolayısıyla bu etkinliğin matematik dersindeki ilgili kazanımla ilişkilendirilmesi, gerekirse bir ders materyali olarak kullanılması ve ilgili kazanıma ilişkin materyal sayısının artıılması konunun kavranmasın kolaylaştırabilir.

On haftalık süreçte ZEP uygulamalarına yönelik tutulan gözlem notlarında önerilerin belirtildiği konular, öğrencilerin hazırbulunuşluklarının dikkate alınması ve buna uygun gruplandırma-eşleştirme yapılması, kullanılabilecek pekiştireçler ile materyal çeşitliliğinin artırılması ve sınıf yönetimi gibi başlıklar etrafında yoğunlaşmıştır. Bunların yanı sıra bir yandan görsel algı becerilerinin iyileştirilmesi hedeflenirken bir yandan da bu becerilerin geometri başarısına olumlu katkısı araştırıldığı için ZEP derslerinin işlenişi esnasında matematik ile ilgili kazanımlara göndermelerde bulunulmasının faydalı olabileceğine ilişkin görüşler de araştırmacı günlüğünde yer almaktadır.

\section{Tartışma ve Sonuç}

Araştırmada ZEP'in, öğrencilerin geometri ders başarılarını istatistiksel olarak anlamlı bir şekilde artırdığı sonucuna ulaşılmıştır. Bu sonuç, geometri ders başarı üzerine yapılmış olan Kandil (2016) ve Bedeloğlu'nun (2016) çalışmalarındaki bulgular ile benzerlik göstermiştir. Sırasıyla 7 ve 10. sınıf 
düzeylerinde gerçekleştirilmiş olan bu çalışmalarda ZEP uygulamalarının geometri başarısına anlamlı katkı sağladığı tespit edilmiştir. Ayrıca, Özcan'ın (2014) matematik ders başarısı üzerinde, Özmen'in (2017) fizik ders başarısı üzerinde ve Özdemir'in (2017) fen bilimleri başarısı üzerinde yaptığı araştırmalarda da ZEP'in anlamlı katkı sağladığı bulunmuştur. Dolayısıyla, alanyazına benzer bir sonuç elde edilmiştir. 8. sınıf öğrencileri üzerinde yürüttükleri çalışmalarda Ünlü'nün (2014) ve Demirkan'ın (2018) bulguları da çalışma ile aynı doğrultudadır. Ünlü'nün (2014) geometri başarısı, duyuşsal özellikler ve uzamsal görselleştirme becerisi arasında tespit ettiği pozitif ve istatistiksel olarak anlamlı ilişki ile Demirkan'ın (2018) uzamsal beceri ve geometri başarısı arasında bulduğu pozitif yönlü ve istatistiksel olarak anlamlı ilişki, çalışmanın sonuçlarıyla örtüşmektedir. Bu araştırmalara benzer alanda Sarı (2010) ve Arıcı (2012) da çalışmıştır. Sarı (2010) yaptığı araştırmada somut materyallerle öğretimin geometri başarısını artırdığını, Arıcı (2012) ise yaptığı çalışmada origami temelli öğretimin uzamsal görselleştirme, geometri başarısı ve geometrik akıl yürütme becerisini artırdığını tespit etmiştir. Alanyazına benzer sonuçların bulunduğu bu iki araştırmanın bulguları da çalışma bulgularıyla benzerlik göstermekte ve birbirlerini desteklemektedir. Duatepe (2004) drama temelli öğretimin dört farklı değişkene etkisini araştırdığı çalışmasının sonucunda da benzer bulgulara ulaşmıştır. $\mathrm{Bu}$ araştırma sonucunda açlar ve çokgenler; çember ve ilişkine başarı testleri, bu başarıların kalıcıllğı testi, Van Hiele geometrik düşünme düzeyleri testi, matematik ve geometri tutum ölçeklerinden alınan puanlara göre deney grubu lehine istatistiksel olarak anlamlı bir farka ulaşılmıştır. Bu bulgular da çalışma sonuçlarıyla örtüşmektedir.

Araştırmada ZEP'in, 4. sınıf öğrencilerinin görsel ayırt etme becerilerine istatistiksel olarak anlamlı ölçüde katkı sağlamadığı; öğrencilerin şekil - zemin ayrımı becerilerine istatistiksel olarak anlamlı ölçüde katkı sağladığ 1 ve şekil - zemin ilişkisi becerilerine ise istatistiksel olarak anlamlı ölçüde katkı sağlamadığı sonucuna ulaşılmıştır. Alanyazında geometri alanında yapılmış olan ve ZEP'in görsel algı üzerindeki etkilerini araştıran herhangi bir çalışmaya rastlanmamıştır. Dolayısıyla doğrudan karşılaştırma imkânı bulunamamıştır. Ancak Altun (2017) yapmış olduğu araştırmada mental aritmetik etkinliklerinin görsel algı üzerindeki etkisini incelemiş ve görsel algının anlamlı olarak arttığını tespit etmiştir. Dolayısıyla çalışmada Altun'un (2017) bulgularına benzer bir sonuç elde edilmiştir. Cengiz (2002) çocukların görsel algı gelişimini destekleyici eğitim programının etkisini araştırdığı çalışma sonucunda beş alt boyutta pozitif yönlü ve istatistiksel olarak anlamlı bir farka ulaşmıştır. Bir diğer çalışmada Özat (2010) öğrenme güçlügü yaşayan çocuklarda Frostig görsel alg1 eğitim programının etkisini araştırmış ve programın çocukların görsel algı gelişimlerini olumlu yönde artırdığını tespit etmiştir. Bayrak (2008) ise görsel eğitimin öğrencilerin uzamsal yeteneklerini geliştirdiğini ve uzamsal problemlere karşı olan tutumlarına olumlu bir etkisi olduğunu yaptı̆̆ çalışma sonucunda ortaya koymuştur. Bu üç araştırmanın da bulguları çalışmanın bulguları ile örtüşmektedir.

Araştırmada öntest ve son test sonuçlarına göre, ZEP'e dayalı etkinlikler 4. sınıf öğrencilerinin matematiğe ilişkin ilişkin olumsuz düşüncelerinin 1,22 puan $(\% 3,2)$ kadar azalmasında katkı sağlasa da bu azalma istatistiksel olarak anlamlı değildir. Diğer taraftan olumlu düşünceler de 1,57 puan $(\% 4,3)$ azalmıştır ancak bu azalma da istatistiksel olarak anlamlı değildir. Ayrıca, ZEP'in matematiğe ilişkin tutumlara bir katkı sağlamadığının farklı bir göstergesi de madde ortalamaları olmuştur. Uygulama sonrası tespit edilen madde ortalamalarına göre öğrenciler 11 olumlu maddeden 10'unda; 15 olumsuz maddeden 8'inde kararsız olduklarını bildirmişlerdir. Bunun yanında madde ortalamalarının hiçbirinde anlamlı bir artış meydana gelmemiştir. Bu sonuçlar Curaoğlu (2012) ve Dönmez'in (2018) uyguladıkları yöntemler sonrasında öğrencilerin matematiğe yönelik tutumlarında olumlu yönde bir değişikliğe ulaşamadıkları bulguları ile örtüşmektedir.

Erdem'in (2015) 7. sınıf öğrencilerinin matematiğe yönelik tutumlarını incelediği çalışmada ZEP'in öğrenci tutumunu anlamlı olarak iyileştirdiği sonucu da dikkate değerdir. Erdem'in (2015) bulgularına benzer olarak Gençoğlu (2013) ve Özdemirli (2011) de araştırdıkları değişkenlerin matematiğe ilişkin tutumu farklı oranlarda olsa da olumlu yönde etkilediği sonucuna ulaşmışlardır. 
Buna benzer şekilde, Pilli (2008), Debreli (2011), Yılmazer (2013) ve Şahin'in (2018) uyguladıkları etkinlikler yoluyla öğrencilerin matematiğe yönelik tutumlarının olumlu yönde arttığına ilişkin sonuçlar eldeki araştırma sonuçlarından ayrışmışlardır. Bu durum ortaokul öğrencileriyle ilkokul öğrencileri arasındaki farklılıklardan, matematiğe ilişkin geliştirilmiş programda yer alan etkinliklerin farklılıklarından ve öğretmen gibi farklı değişkenlerden kaynaklanıyor olabilir.

Araştırmada kullanılan öğrenci günlüklerine bakıldığında öğrencilerin ZEP derslerini eğlenceli buldukları, bazı etkinliklerde zorlansalar da etkinliği bitirmek için hevesle gayret ettikleri, diğer derslere göre ZEP dersinde daha iyi vakit geçirdikleri sonuçlarına ulaşılmıştır. Bunun yanı sıra öğrenciler ZEP derslerinin daha fazla olmasını, fiziki ortamın iyileştirilmesini ve etkinliklerin yarışma formatında gerçekleştirilmesini önermişlerdir. Ayrıca on haftalık süreçte ZEP uygulamalarına yönelik tutulan gözlem notlarında önerilerin belirtildiği konular, öğrencilerin hazırbulunuşluklarının dikkate alınması ve buna uygun gruplandırma-eşleştirme yapılması, kullanılabilecek pekiştireçler ile materyal çeşitliliğinin artırılması ve sınıf yönetimi gibi başlıklar etrafında yoğunlaşmıştır. Bunların yanı sıra bir yandan görsel alg1 becerilerinin iyileştirilmesi hedeflenirken bir yandan da bu becerilerin geometri başarısına olumlu katkısı araştırıldığı için ZEP derslerinin işlenişi esnasında matematik ile ilgili kazanımlara göndermelerde bulunulmasının ve disiplinler arası ilişkilerin gözetilmesinin faydalı olabileceğine dair görüşler de araştırmacı günlüğünde yer almaktadır.

Sonuç olarak, ilkokul 4. sınıfta uygulanan ZEP öğrencilerin geometri ders başarılarına ve görsel algı becerilerine anlamlı bir katkı sağlamaktadır; ancak programın matematiğe ilişkin olumlu veya olumsuz düşünceler üzerinde anlamlı bir etkisi yoktur.

Görsel algının pek çok özelliği, matematik ve geometri ile ilgili temel beceriler ile görsel alg1 arasında önemli ilişkiler olduğunu göstermektedir. Bu kapsamda ilkokul 4. sınıf öğrencilerinin geometri ders ve görsel algı başarısının artırılması için ZEP kullanılabilir. Tutum, diğer duyuşsal özelliklere göre kısa zamanda değişmesi daha zor bir özelliktir. Bu nedenle ZEP'in farklı duyuşsal özellikler üzerindeki etkilerinin araştırılması önerilebilir. Bu çalışma kontrol grubunun işe koşulamadığı bir özel okulda gerçekleştirilmiştir. Devlet okulları ve özel okulların karşılaştırılmasının kontrol gruplu desenler aracılığıyla tekrarlanması sağlanabilir.

\section{Kaynaklar}

Altun, M. (2017). Fiziksel etkinlik kartları ile zeka oyunlarının ilkokul öğrencilerinin dikkat ve görsel algı düzeylerine etkisi. Yayımlanmamış Doktora Tezi, Gazi Üniversitesi Eğitim Bilimleri Enstitüsü, Ankara.

Arıc1, S. (2012). The effect of origami-based instruction on spatial visualization, geometry achievement and reasoning of tenth-grade students. Yayımlanmamış yüksek lisans tezi, Boğaziçi Üniversitesi Sosyal Bilimler Enstitüsü, İstanbul.

Bayrak, E. M. (2008). Görsel öğretimin ilköğretim öğrencisinin uzamsal yeteneğine ve uzamsal yetenek problemlerine yönelik tutumuna etkisinin incelenmesi. Yayımlanmamış yüksek lisans tezi, Orta Doğu Teknik Üniversitesi Sosyal Bilimler Enstitüsü, Ankara.

Bedeloğlu, İ.T. (2016). Geogebra ve video ile zenginleştirilmiş web tabanlı matematik eğitiminin geometri başarısına ve öz-yeterliğe etkisinin incelenmesi. Yayımlanmamış yüksek lisans tezi, Hacettepe Üniversitesi Eğitim Bilimleri Enstitüsü, Ankara.

Cengiz, Ö. (2002). 5.6-6 yaş çocuklarının görsel algı gelişimini destekleyici eğitim programının etkisi. Yayımlanmamış yüksek lisans tezi, Marmara Üniversitesi Eğitim Bilimleri Enstitüsü, İstanbul.

Creswell, J. W. (2003). Research design: Qualitative, quantitative, and mixed methods approaches. CA: Sage.

Curaoğlu, O. (2012). The effects of technology enriched instruction on 6th grade public school students' attitudes and problem skills in mathematics / Teknoloji ile zenginleştirilmiş öğretimin altıncı sını öğrencilerinin matematik dersine karşı tutumlarına 
ve matematik dersindeki problem çözme becerisine etkisi. Yayımlanmamış doktora tezi, Orta Doğu Teknik Üniversitesi Fen Bilimleri Enstitüsü, Ankara.

Dawson, C. (2015). Araştırma yöntemlerine giriş. A. Arı (çev.). Konya: Eğitim Yayıncılık.

Debreli, E. (2011). The effect of creative drama based instruction on seventh grade students' achievement in ratio and proportion concepts and attitude towards mathematics / Yaratıcı drama temelli ögretimin yedinci sınıf öğrencilerinin oran orantı konusundaki başarılarına ve matematiğg yönelik tutumlarına etkisi. Yayımlanmamış yüksek lisans tezi, Orta Doğu Teknik Üniversitesi Sosyal Bilimler Enstitüsü, Ankara.

Demirci, A. (2010). Görsel algı eğitiminin beş - altı yaş çocuklarının görsel algı gelişimlerine etkisi. Yayımlanmamış doktora tezi. Gazi Üniversitesi Eğitim Bilimleri Enstitüsü, Ankara.

Demirkan, H. (2018). 8. sımı öğrencilerinin uzamsal becerileri ile geometri başarıları arasındaki ilişkinin incelenmesi. Yayımlanmamış yüksek lisans tezi, Uşak Üniversitesi Fen Bilimleri Enstitüsü, Uşak.

Dönmez, P. (2018). The effect of using realistic mathematics education on the 7th grade students' mathematical achievement about algebraic expression and attitude towards mathematics / Gerçekçi matematik eğitiminin 7. simı öğrencilerinin cebirsel ifadelerdeki matematik başarısına ve öğrencilerin matematiğe ilişkin tutumlarına etkisi. Yayımlanmamış yüksek lisans tezi, Yeditepe Üniversitesi Eğitim Bilimleri Enstitüsü, İstanbul.

Duatepe, A. (2004). Drama temelli öğretmin yedinci sınıföğrencilerinin geometri başarısına, van hiele geometrik düşünme düzeylerine, matematiğe ve geometriye karşı tutumlarına etkisi. Yayımlanmamış doktora tezi, Orta Doğu Teknik Üniversitesi Sosyal Bilimler Enstitüsü, Ankara.

Erdem, E. (2015). Zenginleştirilmiş öğrenme ortamının matematiksel muhakemeye ve tutuma etkisi. Yayımlanmamış doktora tezi, Atatürk Üniversitesi Eğitim Bilimleri Enstitüsü, Erzurum.

Gençoğlu, T. (2013). Geometrik cisimlerin yüzey alanları ve hacmi konularının öğretiminde bilgisayar destekli ögrretim ile akıllı tahta destekli öğretimin öğrenci akademik başarısına ve matematiğe ilişkin tutumuna etkisi. Yayımlanmamış yüksek lisans tezi, Gazi Üniversitesi Eğitim Bilimleri Enstitüsü, Ankara.

İflazoğlu, A. (1999). Küme destekli bireyselleştirme tekniğinin temel eğitim beşinci sinıf öğrencilerinin matematik başarısı ve matematiğe ilişkin tutumları üzerindeki etkisi. Yayımlanmamış yüksek lisans tezi, Çukurova Üniversitesi Sosyal Bilimler Enstitüsü, Adana.

Kandil, S. (2016). Origami etkinlikleriyle zenginleştirilmiş sorgulama temelli öğretimin ortaokul yedinci sınıf öğrencilerinin yansıma simetrisi konusundaki başarıları, geometri dersine yönelik tutumları ve geometriye yönelik öz yeterlik algıları üzerine etkisinin incelenmesi. Yayımlanmamış yüksek lisans tezi, Ortadoğu Teknik Üniversitesi Sosyal Bilimler Enstitüsü, Ankara.

Marangoz, D. (2018). Mekanik zeka oyunlarının ilkokul 2. sınıföğrencilerinin zihinsel beceri düzeylerine etkisi. Yayımlanmamış yüksek lisans tezi, Sakarya Üniversitesi Eğitim Bilimleri Enstitüsü, Sakarya.

MEB. (2015). Illkokul matematik dersi (1, 2, 3 ve 4. Sinıflar) Öğretim Programı. Ankara: Milli Eğitim Basımevi.

MEB. (2017). PISA 2015 ulusal raporu. Ankara: Milli Eğitim Bakanlığı Basımevi.

Özat, E. N. (2010). Öğrenme güçlü̆̈̈̈̈ yaşayan çocuklarda frostig görsel algı eğitim programının etkisi. Yayımlanmamış yüksek lisans tezi, Abant İzzet Baysal Üniversitesi Sosyal Bilimler Enstitüsü, Bolu.

Özcan, D. (2014). Anadolu Lisesi öğrencilerine uygulanan matematik tarihiyle zenginleştirilmiş öğretim programının matematik başarısına etkisi. Yayımlanmamış yüksek lisans tezi, İstanbul Sabahattin Zaim Üniversitesi Sosyal Bilimler Enstitüsü, İstanbul.

Özdemir, G. (2017). Üstün yetenekli öğrencilere yönelik zenginleştirilmiş öğretim programının bilimsel süreç becerilerine ve başarıya katkısına ilişkin eylem araştırması. Yayımlanmamış yüksek lisans tezi, Hacettepe Üniversitesi Eğitim Bilimleri Enstitüsü, Ankara.

Özdemirli, G. (2011). İşbirlikli öğrenme yönteminin öğrencinin matematik başarısı ve matematiğe ilişkin tutumu üzerindeki etkililiği: Bir meta analiz çalı̧̧ması. Yayımlanmamış yüksek lisans tezi, Çukurova Üniversitesi Sosyal Bilimler Enstitüsü, Adana.

Özmen, K. (2017). Epistemolojik yönden zenginleştirilmiş öğretim metodunun dokuzuncu sinıf öğrencilerinin fizik ile ilgili kişisel epistemolojilerine ve fizikteki başarısına etkileri. Yayımlanmamış doktora tezi, Ortadoğu Teknik Üniversitesi Fen Bilimleri Enstitüsü, Ankara. 
Pilli, O. (2008). Bilgisayar destekli öğretimin 4. sınıf matematik dersindeki başarı, tutum ve kalıcıliğa etkisi. Yayımlanmamış yüksek lisans tezi, Orta Doğu Teknik Üniversitesi Sosyal Bilimler Enstitüsü, Ankara.

Sarı, S. (2010). Somut materyallerle öğretimin dördüncü sınıf öğrencilerinin geometri başarısına etkisi. Yayımlanmamış yüksek lisans tezi, Orta Doğu Teknik Üniversitesi Sosyal Bilimler Enstitüsü, Ankara.

Senger, B. (2010). Görsel algı ve matematik ilişkisi. Yayımlanmamış yüksek lisans tezi, Abant İzzet Baysal Üniversitesi Sosyal Bilimler Enstitüsü, Bolu.

Şahin, S. (2016). Zenginleştirilmiş eğitim programının öğrencilerin eleştirel düşünme becerileri, problem çözme becerileri ve matematik kaygısı üzerine etkisinin incelenmesi. Yayımlanmamış doktora tezi, Dumlupınar Üniversitesi Eğitim Bilimleri Enstitüsü, Kütahya.

Şahin, Z. (2018). Geometri öğretiminde kavram karikatürü kullanımının beşinci sınıföğrencilerinin matematiğe yönelik tutumlarına ve erişi düzeylerine etkisi. Yayımlanmamış yüksek lisans tezi, Dokuz Eylül Üniversitesi Eğitim Bilimleri Enstitüsü, İzmir.

Ünlü, M. (2014). Geometri başarısını etkileyen faktörler: Bir yapısal eşitlik modellemesi. Doktora Tezi, Necmettin Erbakan Üniversitesi Eğitim Bilimleri Enstitüsü, Konya.

Yıldırım, A., Şimşek, H. (2013). Sosyal bilimlerde nitel araştırma yöntemleri. Ankara: Seçkin Yayıncılık.

Yılmazer, Z. (2013). Geometri öğretiminde bir kukla modeli tasarlanması ve kukla modeli ile geometri öğretiminin matematiğe yönelik tutuma etkisinin incelenmesi. Yayımlanmamış yüksek lisans tezi, Gaziosmanpaşa Üniversitesi Eğitim Bilimleri Enstitüsü, Tokat. 